\title{
Review of Best Practice Approaches in Combatting Vulnerability to Flood Disaster Risk in Ala-River Flooding Akure, Ondo State, Nigeria
}

\begin{abstract}
Keywords: Flood disaster risk; Vulnerability to flood disaster; Participatory risk disaster reduction approach

Abstract

Disaster of whatever nature, either caused by natural factors or by human-induced factors, can be very destructive, often time led to loss; of lives, infrastructure, economic investments such as landed properties and farm crops. Preparing for such disaster can help saved lives and properties, reduce vulnerabilities, while at the same time help reduce public health issues. This paper review some selected literature related to approaches used in combatting vulnerability to flooding, some of the factors considered were socioeconomic indices, among which are; educational status, household income status, and employment status. Linking the reviewed literatures to the situations in the study area, the paper tried to understand the complexities existing between these indices, in the same vein participatory approaches were reviewed to understand how this approach can aid the participation of stakeholders in ensuring the reduction of vulnerability to flood disaster risk. To help in reducing vulnerabilities to flood disaster risk, the paper conclude with recommendations concerning enhancement of socioeconomic status of vulnerable residents of the study area, examining and adjusting case studies reviewed to suit Ala river flood disaster risk for application purposes so as to increase peoples' resilience to flood disaster risk by strengthening the socioeconomic status of the residents of the study area, among others.
\end{abstract}

\section{Introduction}

Human being is constantly facing both natural and man-made disaster of different types, but in most instances, disaster(s) occurs naturally, but people are vulnerable to disasters because of human actions or inactions towards disasters, natural disaster such as floods are becoming more complex and climate change leads to a greater potential for adverse impacts [1]. Normal floods are expected and generally welcomed in many parts of the world as they provide rich soil, water and a means of transport, but flooding at an unexpected scale (damaging flood) and with excessive frequency causes damage to life, livelihoods and environment [2]. As much as this assertion stands, natural disaster such as floods are often time than not, being influenced or caused by human activities and complemented by climate change, because if actions have been taken earlier before the sudden adverse climatic conditions, the level of human vulnerability to climate change-prone disaster will have been reduced considerably.

Although it is observed that, natural disasters have its huge impacts at both local and urban levels, but its impact is hugely felt in the urban centre than the countryside because of huge investment and population concentration in the urban centers. Also [3], emphasized

\section{Environmental Studies}

\author{
Bakare Ganiyu Olalekan* and Anjorin Fadesola \\ Department of Urban and Regional Planning, Faculty of \\ Environmental Studies, Rufus Giwa Polytechnic, PMB 1019, Owo, \\ Ondo State, Nigeria

\section{*Address for Correspondence} \\ Bakare Ganiyu Olalekan, Department of Urban and Regional Planning, Faculty \\ of Environmental Studies, Rufus Giwa Polytechnic, PMB 1019, Owo, Ondo \\ State, Nigeria, E-mail: gbakare@rugipo.edu.ng \\ Submission: 19 October, 2016 \\ Accepted: 10 March, 2017 \\ Published: 15 March, 2017 \\ Copyright: () 2017 Olalekan BG. This is an open access article \\ distributed under the Creative Commons Attribution License, which \\ permits unrestricted use, distribution, and reproduction in any medium, \\ provided the original work is properly cited.
}

that, in developing world, a very high proportion of urban population growth and spatial expansion takes place in dense, lower-quality informal settlement often referred to as "slum". These are located in both city-centre and peripheral, suburban or peri-urban locations and are frequently at highest risk. The concentration of the poor within these areas, which typically lack adequate housing, infrastructure and service provision, increases the risk of flooding and ensures that flood impacts are worst for the disadvantaged.

\section{Flooding and flood disaster risk}

Flood can occur as both frequent and rare events, as short and long duration, and produce adverse impact across a range of magnitudes, human processes such as urbanization and structural defenses (e.g., levees, dams, sea walls) have a large influence on the movement and severity of flooding, ameliorating impacts in some cases, but amplifying them in others. Ongoing changes in population, land use, and climate, are widely believed to presage an intensification of flood disasters; the unique characteristics of floods and their wide array of manifestations suggest that social vulnerabilities to floods could be distinct from other hazards [4]. Flood by nature are complex events caused by a range of human vulnerabilities, such as, inappropriate development planning and climate variability are some of these factors [5]. Flood can be predicted to a reasonable extent, with the exception of flash floods, whose scale and nature are often less certain [6]. However flood becomes a disaster when people and (livelihoods) or properties are vulnerable to floodwater, over the past decades, the pattern of floods across all continents has been changing, becoming more frequent, intense and unpredictable for local communities, particularly as issue of development and poverty have led people to live in areas vulnerable to flooding, so also is lack of access to buildable titled lands. Studies conducted by [7-9] revealed that flood occur mainly in three forms-coastal flooding, river flooding and urban flooding, while coastal flooding occurs in the low lying belt of the mangrove and fresh water swamps along the coast, river flooding occurs in the flood plains of the larger rivers, while short-lived flash floods are associated with rivers in the inland areas and sudden heavy rains that change into destructive torrents within a short period. Also, 
Citation: Olalekan BG, Fadesola A. Review of Best Practice Approaches in Combatting Vulnerability to Flood Disaster Risk in Ala-River Flooding Akure, Ondo State, Nigeria. J Environ Stud. 2017;3(1): 5.

urban flooding occurs in towns or cities, on flat or low lying terrain especially where little or no provision has been made for surface drainage, or where existing drainage has been blocked with municipal waste, refuse and eroded soil sediments.

Flood becomes a disaster risk when people are exposed and vulnerable to disaster risk, however, a disaster is serious disruption of the functioning of a people, a community, or a society, involving widespread human, material, economic or environmental losses and impacts, which exceeds the ability of the affected community or society to cope using its own resources [10]. While, disaster risk is the potential disaster losses, in lives, health status, livelihoods, assets and services, which could occur to a particular community or a society over some specified future time period [10]. However, floods as sociological phenomenon transcend beyond hydrological conditions, which also borders on the well-being of human societies, such as changing social environments because of urbanization, sprawl, increasing densities, or industrialization which in turn may affect vulnerability to floods of larger segments of population. Also is the response to flood, which are becoming more complex as more interdependent systems are affected and the calls for more integrated, long-range planning are increasing; and, response to flood which require also broader mobilization of institutions and people in order to accommodate adaptive policies for resources scarcities, climatic vagaries, and the uncertainties of future environments [11]. To understand vulnerability to flooding, various factors and indicators such as; physical, socioeconomic (social and economic) vulnerabilities at the individual, community State and National levels are reviewed in this paper, without which if not properly put into perspectives, it would be impossible to proffer recommendations that can reduce the levels of vulnerabilities to the flood disaster risk.

\section{Vulnerability to flood disaster risk (Socioeconomic indicators)}

The sociological phenomenon has been linked with floods and society for a long time, i.e., the total impacts of floods and its consequences, or challenges of responding to catastrophic flood disaster in an increasingly complex and fast-changing socioeconomic context. In most instances, socioeconomic indicators in a community are most commonly used in measuring social vulnerability, this varies in terms of income, employment status and marital status among others, while it is important to characterize population by broad categories of dominant socioeconomic indicators, it is important to understand how each indicator combines with others to generate interactive vulnerabilities [12]. Common socioeconomic status indicators include measurements of household income, poverty, unemployment, educational status, wealth, inequality and home value, at the individual level, lack of resources, power relationships, poverty, and marginalization translate into social vulnerability through access to resources, coping behavior and stress [13]. Also, at the community level, social vulnerability is determined by relative distribution of income, access to resources, and diversity of economic assets [14].

Although, research has shown that, some commonly used socioeconomic indicators are strongly correlated, thus, it is important to use either a composite measure of social vulnerability or subset of these indicators to measure the vulnerability of a community
$[12,15]$. However, the vulnerability of a community to flood hazard is commonly measured using socioeconomic indicators or calculating physical flood extents, although, their combined impact is often ignored. Geographical Information System based approaches have been used in some cases to understand the coastal/river flood vulnerability by overlying the hydrodynamic models predicted flood areas over land surface elevations, but this approach does not incorporate socioeconomic vulnerability $[9,16]$. There are few studies that consider combined socioeconomic and physical vulnerability $[11,17]$. The vulnerability assessment is often complex, requiring significant amount of data, such as surface elevation surveys and development of detail hydrodynamic models, are expensive. It was equally observed that, people with the fewest psychological, social, economic, and political resources often disproportionately occupy the most hazardous geographical areas and the oldest, most poorly maintained buildings, which results in the greatest physical impacts such as casualties and property loss during a disaster [18].

Often time, not only do poorer and marginalized populations live in highly exposed zones with less employment and housing opportunities, they are also less protected by formal institutions, such as those that provide disaster mitigation and recovery assistance [4]. It was observed that, the poor are less likely to have the income or assets needed to prepare for a possible disaster and recovery efforts, while the wealthy people may have higher monetary value of economic and material losses, the losses sustained by the poor are far more devastating in relative terms [8]. In a similar case, people with higher education are expected to better prepare for a disaster and are less vulnerable to disaster impacts, vulnerability of women increases not only due to their low income, in general, but also from their higher responsibilities because of their roles as mother and caregivers, which limits their ability to seek safety while caring for children and very old people who require assistance [15].

\section{Risk disaster reduction (Participatory approach)}

Participatory risk disaster reduction approach in disaster challenges represent a radical approach that has created a noticeable shift in disaster risk reduction research away from top-down directive or approaches to bottom-up approaches/planning [19]. It is argued that participatory risk reduction approach is a mechanism provided for indigenous people to participate in and direct plans or agendas [20]. Participatory risk disaster approach involved a shift away from the more traditional form of extractive research or project led by outsiders, which in many cases is not conducive to an understanding of the locality and situation as a whole [2,17,21]. Participatory approaches/techniques in particular have been employed to address challenges and develop ways to interact with and involve local people in making decisions about their future [22].

The point being stressed here is the involvement of local people from conception of projects, plans, and strategies to its implementation stages. Participatory approaches are a bundle of project/research techniques placing emphasis on participant producing detailed accounts of project using their own best approaches and frameworks [23-25]. The idea of participatory approach came from a result of the perceived limitations of the top-down approach through a promotion of participation and an involvement of local people. Participatory 
Citation: Olalekan BG, Fadesola A. Review of Best Practice Approaches in Combatting Vulnerability to Flood Disaster Risk in Ala-River Flooding Akure, Ondo State, Nigeria. J Environ Stud. 2017;3(1): 5.

approach in risk disaster reduction aimed at being interactive, involvement and collaborative, providing a meaningful research experience that both promotes learning and generates research data through a process of 'guided discovery'. Going forward, 'guided discovery' is a constructivist learning theory where the learner draws on their past experience or lessons learnt from other places and existing knowledge to discover facts, relationships and new truths [26].

\section{The Study Area (Ala-River)}

Flooding in the study area has been wrecking havocs since 2010 on the residents of the affected areas and their materials. Akure, where the study area is located is the capital city of Ondo State, in south-western part of Nigeria, located in latitude $7^{0} 15^{1} \mathrm{~N}$ and $7^{0} 28^{1} \mathrm{~N}$ of the equator and longitude $5^{0} 6^{1} \mathrm{E}$ and $5^{0} 21^{1}$ East of the Greenwich meridian, the total land area is approximately $41.2 \mathrm{~km}^{2}$ [24]. The rate of urbanization in Akure has been on the increase because of the dual roles it plays as the State capital and local government headquarter, hence the population has been on the rise, with the concentration of government administrative activities at both the local and state levels, coupled with other commercial and few industrial activities in the city, where the last official population figure of Akure stands at $3,53,211$ [27].

Ala-River traverse the city of Akure, but the study area as presently occupied has some structures built on the supposedly buffer (setback) of the river body, which in turn put the residents of these locations in highly vulnerable positions to flood disaster risk. However the challenges being faced by the occupants of these areas do not receive the required government attentions because, the residents are often time than not viewed as illegal occupants who do not deserved the necessary government attention and assistance. Any response to the problems of this particular group of people should be participatory and inclusive in nature, so as to reduce their levels of vulnerabilities [28].

\section{Flooding in the Study Area}

Most of the houses located in the study area are built illegally with no existing physical plans, thereby making it difficult for construction/ provision of public infrastructure. Most house owners in the study area do not have legal titles of the existing properties, hence making it difficult for government at the city and local level to provide needed infrastructure. Therefore, whenever there is heavy downpour of rains little or no assistance comes from the government, however in recent times flooding has been a recurrent disaster because of heavy rain and storm water that overflows it bank, since the location of the study area is poor and there is absence of infrastructure to handle storm water effectively, the results or consequences of this has always been havocs on lives and properties, also, this damage(s) has been aggravated by unplanned physical development around this illegal settlement with absence of drainage and storm water facilities, the level of poverty in the study area is deemed high, with most people living in overcrowded and squalid condition, where sewage and refuse management equipment are conspicuously missing [24].

However, on the part of the city and local governments that are legally bound to ensure safety of life and property of this group of residents, could not provide any assistance when needed the most because most of the residents do not possess the legal titles, also, those who possess the documents (land titles), do not complied with Town Planning rules and regulation as regards the required building (i.e. $30 \mathrm{~m}$ setback) which contravenes development control regulations. However, 312 buildings were affected to be on the water body set back in the study carried out by [29] through the use of GIS in identifying buildings liable to flooding in the study area. After due consideration of the flood disaster risk challenges faced by the residents of Ala River, case studies of similar situations were reviewed in this paper, so as to finding recommendations that may eventually reduced vulnerability to flood disaster risk and build an inclusive society, some of the reviewed best practices are discussed.

\section{Graveyard pond Philipi flooding in Cape Town, South Africa} review

The case of Cape Town South Africa is similar to the study area of this paper, information as regards flood risks were not formally available in this affected community, while, in the formal neighborhoods, information that helps to combat flooding were actually supplied by the residents of the neighborhoods and properly documented. Hence the pool of information provided by the residents of the formal neighborhoods helped the government's risk management agencies to estimate, plan and prepared sufficiently for flood risk. Hence solution provided by CTCC (Cape Town City Council) risk management team were generic which does not take the peculiarity of the informal settlement into consideration.

In the case of the best practice about the informal coastal settlement flooding in Cape Town the Public Participatory Geographical Information System (PPGIS) was used, its aim is to use GIS to provide information that strengthen involvement of the community or informal settlement or marginalized groups in decision making [9,30-32], to source for date where non is officially available on flooding occurrence [33], used GIS and local knowledge to contribute to proper planning and resource allocation for disaster preparedness in Thua Thien Hue, Central Vietnam, community information included existing infrastructure, demographic and socio-economic conditions as well as information on the damage and loss caused by previous flood disaster [34].

Hence Participatory Rural Approach Technique (PRA) such as focus groups as similar to PPGIS were used as in the case of this informal settlement in Cape Town to highlight the most flood prone residential units as well as factors that contributes to flood vulnerability or the use of questionnaire as applied by $[35,36]$ and [17]. The social demographic data process collection steps are as follow;

Identification of informal settlement: This specifically emphasized on identification of the affected area(s)/community with a view to conduct reconnaissance survey and be familiar with the present situation,

Discussion with community leaders: This strategy emphasized the involvement of community stakeholders, since these set of leaders are closer to the affected community than government, hence the importance of this step cannot be underestimated in achieving expected results, 
Citation: Olalekan BG, Fadesola A. Review of Best Practice Approaches in Combatting Vulnerability to Flood Disaster Risk in Ala-River Flooding Akure, Ondo State, Nigeria. J Environ Stud. 2017;3(1): 5.

Development of questionnaires: This stage of the strategy serves as the best means of asking required questions to arrive at practicable suggestion to the flood risk disaster,

Enumeration and mapping (through GIS application): This is another step that involved both the enumeration of collected data from the designed questionnaires and the use of Geographical Information System to arrive at accurate mapping of the affected area,

Data integration and analysis: This stage involves integration and analysis of the collected data from the field into the GIS map production, where detailed analysis of the whole project will be produced,

Data verification by community: This is the last stage of the strategy, where map generated from both the Data collected and GIS map production will be display before the affected members of the community to contribute their final inputs/corrections before the its final approval from the community.

\section{Asian disaster preparedness centre-community based disaster risk management (CBDRM) review}

Community-Based Disaster Risk Management (CBDRM) is a participatory approach used to build resilience in some parts of Asia, and it simply refers to the process of disaster risk management in which the community at risk is actively engaged in the identification, analysis, treatment, monitoring and evaluation of disaster risks in order to reduce vulnerabilities and enhance capacities. This means that the people are at the centre of the decision making and implementation of disaster risk management activities identified.

The involvement of the most vulnerable is paramount and the support of the least vulnerable is necessary. In CBDRM, local and national governments are involved and supportive [6,37,38]. This process has seven (7) sequential stages, which can be used before and after the occurrence of a disaster to reduced future risks. Each stage grows out of the preceding stage and lead to further actions, all together can build up a planning and implementation system, that can become a powerful disaster risk and management tool, these are the stages;

Selecting/Identifying the Community or Settlement

- Choosing the vulnerable settlement for action

\section{Rapport Building and Understanding the Community}

Building the relationship and trust within the people to understand the position of the community in terms of social, political and economic aspect of their life

\section{Participatory Disaster Risk Assessment (PDRA)}

Identifying the risks that the community faces and how people overcome those risks, such as hazard assessment, vulnerability assessment, people's perception of risk is equally considered Participatory Disaster Management Planning

The people should identify risk reduction measures themselves that could reduce vulnerabilities and enhance capacities, which are then translated to disaster risk management plan
- Building and Training a community Disaster Risk Management Organization, If the community does not have one on ground, it is better to build one, train the leaders to build capacities of their people

\section{Community Managed Implementation}

- The community disaster risk reduction management should lead to implementation of the community plan and motivate others for their support

Participatory, Monitoring and Evaluation

This involves a communication system in which information flow amongst all the people involved in the project; the community, implementing staff and the support agency, concerned government agencies and donor agencies.

It is also noted from this study that a group of capacity training organization is expected to be in place, to ensure capacity building of the vulnerable people on how to provide workable solutions to identifying causes which made their community prone to disaster risk.

\section{Recommendations}

The following recommendations were made after careful considerations of best practices lessons and review of literatures.

- $\quad$ The use of integrated flood management approach: future development plans of the study are should take into consideration the issue of urban drainage system that would protect the vulnerability of the residents and the environment.

Bottom up and Participatory Approach should be employed: since the community/people is key in ensuring sustainability of any recommended solution to flood disaster risk, the community or the people should be proactively involved in every step of the would be solutions to the flood problems as can be seen from the two best practice case studies reviewed.

- $\quad$ Tackling of related issues to vulnerability of residents to flood disaster risk should not be ignored: whatever recommendations that may arise as a result to vulnerability to flood disaster risk has to address the problems of employment status, income status, gender status among others, so as to create an adaptation/resilience mechanisms against flood disaster and strengthening the residents preparedness against such disaster.

- Application of early warning system: the advent of technology can now assist in predicting the extent of flood disaster risk, which can go a long way to prevent and reduce flood disaster to manageable levels.

\section{Conclusion}

For effective protection of lives and properties against flooding the issue of vulnerability to flooding disaster risk must be addressed along with the issue of participatory processes in combating flooding. However it must be noted that there is no one fixed solution to flood disaster risk, but an integrated approaches that involves all the concerned stakeholders in jointly participating and handles the problems collectives so that a sustainable environment can be 
Citation: Olalekan BG, Fadesola A. Review of Best Practice Approaches in Combatting Vulnerability to Flood Disaster Risk in Ala-River Flooding Akure, Ondo State, Nigeria. J Environ Stud. 2017;3(1): 5.

ascertained. Similarly, recommendations put forward in this paper can go a long way to reducing the vulnerability of the residents of the study area to flood disaster risk, if fully implemented by the concerned stakeholders.

\section{References}

1. Aalst M, Burton I (2002) The last straw: integrating natural disaster mitigation with environmental management. Disaster risk management working paper No. 5. The World Bank, Washington, DC.

2. ALNAP (2008) Flood disasters: learning from previous relief and recovery operations. Provention Consortium.

3. Jha AK, Bloch R, Lamond J (2012) Cities and flooding: A guide to integrated urban flood risk management for the $21^{\text {st }}$ Century. The World Bank, Washington DC.

4. Pain R, Francis P (2003) Reflections on participatory research. Area 35: 46 54.

5. Wisner B (2004) At risk: natural hazards, people's vulnerability and disasters, $\left(2^{\text {nd }} e d n\right)$. Psychology Press

6. ADPC (2005) Integrated flood risk management in Asia, Bangkok: Asian Disaster Preparedness Center and United Nations Development Programme.

7. Adeloye AJ, Rustam R (2011) Lagos (Nigeria) flooding and influence of urban planning. J Urban Des Plan 164: 175-187.

8. Comfort L, Wisner B, Cutter S, Pulwarty R, Hewitt K, et al. (1999) Reframing disaster policy: the global evolution of vulnerable communities. Environ Hazard 1: 39-44.

9. Ghose R, Elwood S (2003) Public participation GIS and local political context: propositions and research directions. URISA J 15: 17-24.

10. UNISDR (2009) Terminology on disaster risk reduction.

11. Chambers $R$ (1994) The origins and practice of participatory rural appraisal. World Dev 22: 953-969.

12. Chambers R (1994) Participatory rural appraisal (PRA): analysis of experience. World Dev 22: 1253-1268.

13. Adger WN (1999) Social vulnerability to climate change and extremes in coastal Veitnam. World Dev 27: 249-269.

14. Flanagan BE, Gregory EW, Hallisey, EJ, Heitgerd JL, Lewis B (2011) A socia vulnerability index for disaster management. J Homel Secu Emerg Manag 8.

15. Chang LF, Huang SL (2015) Assessing urban flooding vulnerability with an emergy approach. Landsc Urban Plan 143: 11-24.

16. Fielding JL (2012) Inequalities in exposure and awareness of flood risk in England and Wales. Disasters 36: 477-494.

17. Bouchard B, Goncalo A, Susienka M, Wilson K (2007) Improving flood risk management in informal settlement of Cape Town. Forum for Agricultural Risk Management in Development, pp.86.

18. Ivanitz M (1999) Culture, ethics and participatory methodology in crosscultural research. Aust Aborig Stud 2: 46-58.

19. Folorunsho R, Awosika L (2001) Flood mitigation in Lagos, Nigeria through wise management of solid waste: the case of Ikoyi and Victoria Islands. Coastal region and small island papers 12: papers.
20. Cutter SL, Emrich CT, Webb JJ, Morath D (2009) Social vulnerability to climate variability hazard: a review of the literature. Final report to Oxfam America. Hazard and Vulnerability Research Institute, Department of Geography, University of South Carolina, Columbia, SC, USA.

21. Cutter SL, Finch C (2008) Temporal and spatial changes in social vulnerability to natural hazards. PNAS 105: 2301-2306.

22. Chakraborty J, Tobin GA, Montz BE (2005) Population evacuation: Assessing spatial variability in geophysical risk and social vulnerability to natural hazards. Nat Hazard Rev 6: 23-33.

23. Bruner JS (1961) The act of discovery. Harvard Edu Rev 31: 21-32.

24. Fadairo G (2013) An empirical evidence to the urban storm water crisis and the way out in Akure, Nigeria. European Int J Sci Technol 2: 53-66.

25. Mercer J, Kelman I, Lloyd K, Suchet-Pearson S (2008) Reflections on use of participatory research for disaster risk reduction. Participatory Research for Disaster Risk Reduction. AREA 40: 172-183

26. Binns T, Hill T, Nel E (1997) Learning from the people: participatory rura appraisal, geography and rural development in 'new' South Africa. Appl Geogr 17: 1-9

27. NPC (2006) National Population Commission, Nigeria. Census Figure.

28. Yahaya S, Ahmad N, Abdalla RF (2010) Multicriteria analysis for flood vulnerable areas in Hadejia-Jama'are River Basin, Nigeria. European J Sci Res 42: 71-83.

29. McGuigan K, Webster T, Collins K (2015) A flood risk assessment of Lahave River Watershed, Canada using GIS techniques and unstructured grid combined river-coastal hydrodynamic model. J Mar Sci Eng 3: 1093-1116.

30. Seiler RA, Hayes M, Bressen L (2002) Using the standardized precipitation index for flood risk monitoring. Int J Climatol 22: 1365-1376.

31. Louis RP (2007) Can you hear us now? Voices from the margin: using indigenous methodologies in geographic research. Geogr Res 45: 130-139.

32. Kulkarni AT, Mohanty J, Eldho TI, Rao EP, Mohan BK (2014) A web GIS based integrated flood assessment modeling tool for coastal urban watersheds. Comput Geosci 64: 7-14.

33. Tran P, Shaw R, Chantry G, Norton J (2009) GIS and local knowledge in disaster management: A case study of flood risk mapping in Viet Nam. Disasters 33: 152-169.

34. Evan V (1995) Socio-economic impacts and consequences of extreme floods. U.S. - Italy Research Workshop on the Hydrometeorology, Impacts, and Management of Extreme Floods, Perugia, Italy.

35. Abbot J (2000) An integrated spatial information framework for informal settlement upgrading. Int Ach Photogramm Remote Sens 33: 7-16.

36. Rufat S, Tate E, Burton CG, Maroof AS (2015) Social vulnerability to floods: Review of case studies and implications for measurement. Int J Disaster Risk Reduction 14: 470-486.

37. Abarquez I, Murshed Z, ADPC (2004) Community-based disaster risk management: Field practitioners' handbook. Asia Disaster Preparedness Centre, pp. 1-150.

38. Morrow BH (2013) Community resilience: A social justice perspective. Community and Regional Resilience Initiative. 